\title{
THE PROFILE OF ENGLISH TEACHERS' PROFESSIONAL COMPETENCE AND STUDENTS' ACHIEVEMENT AT SMA NEGERI 1 ENREKANG
}

\author{
Umiyanti Jabri \\ STKIP Muhammadiyah Enrekang \\ Email: umiyatjabri@gmail.com
}

\begin{tabular}{|c|c|}
\hline Keyword & Abstract \\
\hline $\begin{array}{l}\text { Teacher, } \\
\text { Professional, } \\
\text { Competence, } \\
\text { Achievement, }\end{array}$ & $\begin{array}{l}\text { This research was aimed at identifying the profile of English teachers' } \\
\text { professional competence and students' achievement at SMK Negeri I Makassar. The } \\
\text { profile of English teachers' professional competence was specified based on the two sub- } \\
\text { competences in the National Standard of Education, in section 28, sub-section } 3 \text { point c. } \\
\text { The researchers employed descriptive evaluation method. The population of this } \\
\text { research was English teachers of SMK Negeri } 1 \text { Makassar. The sample was purposive } \\
\text { sampling technique in which researcher chose the three certified English teachers as the } \\
\text { sample. They were observed in the classroom while teaching and learning process and } \\
\text { were also interviewed in relation to the implementation of professional competence in } \\
\text { their teaching. The result showed for the first sub- competence, the teachers show their } \\
\text { effort in selecting, determining, and organizing the materials by making their own } \\
\text { module. In terms of the second sub-competence, all of the teachers have less effort in } \\
\text { developing their professional competence. It can be concluded that the three English } \\
\text { teachers still need more improvement. in terms of students' achievement, the data from } \\
\text { findings indicates that the highest students' score is from teacher III. Meanwhile, the } \\
\text { highest score of teacher professional competence among those teachers is teacher I. It } \\
\text { indicates that many factors such as intelligence type, motivation, attitude, and condition } \\
\text { of learning taking place that could affect the students' achievement, not only the } \\
\text { professional competence. }\end{array}$ \\
\hline
\end{tabular}

\section{INTRODUCTION}

Being a teacher is a complex profession in which teachers meet various students' background; social and intellectual. Successful teachers are not simply responsible for transferring knowledge, but they must also transfer it effectively and successfully, and for that reason alone, they should organize classrooms, implement effective classroom pedagogy and work cooperatively with a diversity of students and colleagues to transfer the knowledge effectively and successfully (McCaughtry et.al in Zulfikar, 2009:13).

In Indonesia, public assumes that being a teacher is an easy job. Indeed, teachers also assume that the duties of a teacher are easy, manageable and could be carried out successfully. Due to this paradigm, most teachers are not serious in gaining knowledge during teacher training. As a result, it brings negative effects to the teaching profession. In reality, being a teacher is not an easy task because teachers have to fulfill 
parents' expectations and to ensure that students are well-educated. Therefore, all teachers have to improve their teaching skills and knowledge. The elements and domains which are supposed to be fulfilled by all teachers are personality, intellectual, emotion, inter-personal skills, intra-personal skills and creativity in teaching. Despite the elements and domains that are supposed to be fulfilled by all teachers, many Indonesian teachers are lack in teaching competence (Azra in Zulfikar, 2009:14).

According to Permendiknas No $16 / 2007$, the teacher must have four competences; pedagogical competence; personal competence; social competence, and professional competence. In relation to teachers' competence, the success of the teaching materials in relation to teaching content is influenced competence.

Professionally, professional teachers should have capability to plan and implement the learning activities to learning objectives. In achieving these learning objectives, teachers must not only convey learning materials, but also must update and master the learning material that they present to the students; in this case the teachers need to develop their professional competence.

To develop this competence, the government has a program named certificate program lasting from around July 2007 until now. In 2007, the program was executed in the form of portfolio then changed into PLPG around October 2010. For the teachers who cannot pass through portfolio, they will get training program, while for the teachers who cannot pass through PLPG, they have to face the remedial program. However in 2013, there was a little change, every candidates of teacher certification must attend Initial Competency Exam (UKA) or currently called UKG. Those who pass then they are entitled to follow PLPG, for those who do not pass they have to follow the UKA / UKG next year. If it does not pass again in 2015, then they are required to participate in Professional Teacher Education (PPG) for 1-2 semesters to obtain teacher certification. In the Teacher Competency Test, besides pedagogical competence, professional competence is also to be tested. So that, each teacher must truly master the professional competence.

Professional competence of the teacher is obviously preformed in mastering scholarly and substance related to learning process. In mastering the substance of scholarly, teacher is required to master the content of the field study under their control. In this case, a teacher should understand the curriculum and teaching materials, understand the concepts, methods, and structures of science that deals with the material being taught. Whereas, in mastering the substance related to the learning process the teachers should conduct an analysis of learners characteristics, prepare the design of learning process according to the characteristics of learners and teaching materials, create a conducive atmosphere to the learning process, implement a conducive teaching and learning process for students to learn, and choose the best medium of learning media for students. When the teacher can apply those things effectively, hopefully the students could achieve the learning objectives. Based on the background explained above, the researcher is interested in one of the four teacher competencies; that is professional competence and its effect in students' achievement so that she conducts a research under the title: The Profile of English teachers' professional competence and students' achievement at SMA Negeri 1 Enrekang. 


\section{DISCUSSION}

Many researchers have proved studies in term of teacher competence as follows:

Sikki, Rahman, Hamra, and Noni (2013) found that the primary school teachers of English in South Sulawesi province in Indonesia have poor level of professional and pedagogic competences. The level is still below the intended minimum level. Therefore, this study strongly recommends the continual professional development for the teachers, especially in-service training. They concluded that the competence of English teachers in primary school in Indonesia needs improvement in their professional and pedagogic competences.

Syahruddin, Andi, Rahman, and Sihes (2013) stated that there is a significant relationship between the teachers' professional competence and the implementation of SBM (School- Based Management).. In other words, the increase of the teachers' professional competence is significantly related to the increase of the implementation of SBM Furthermore, the results indicated that teachers' professional competence significantly affect the implementation of SBM. Additionally, the qualitative results from the interviews indicated that teachers' professional development in the form of performance, commitment, and motivation improvement can be considered as an important strategy to improve the quality of SBM.

Mustafa (2013) showed that the level of professional competencies in Riau is generally at an average level. The result shows that there is significant difference between female and male teachers in terms of mastery of professional competency. In addition, the data shows that there is significant difference between more experienced and less experienced teachers regarding mastery of professional competency. The implication is that the program, run by schools or ministry of education, to implement to upgrade the professional competency of teachers should consider the teachers' backgrounds to make sure its effectiveness.

Considering the importance of teachers' professional competence as the one of the competencies that the professional teacher should have, the researcher is interested in identifying the profile of English teachers' professional competence in a regency to get more information in certain area.

\section{Some Pertinent Ideas}

The researcher wants to view, analyze then describe the profile of English teachers' professional competence at SMA Negeri 1

Enrekang in the teaching and learning process and students' achievement towards it. This part discusses about the Profile, Teachers' Competence, Professional Competence, SubCompetences of Professional Competence, and Some Issues that teacher should pay attention in implementing the professional competence.

\section{Profile}

There are some definitions of profile according to different sources. In Cambridge Advanced Dictionary, profile refers to a short description of someone's life, work, character, etc. In another source, a profile is a graph, diagram, piece of writing, etc. presenting or summarizing data relevant to a particular person or thing (Webster's New World College Dictionary). While in Dictionary Reference, Profile is defined as a set of characteristics or qualities that identify a type or category of person or thing (dictionary. reference. Com/browse profile). 
Based on some definitions above, it is concluded that profile is an image of character, quality, or a brief biography that identify a type or category of a person or group or thing. While in this research, profile is the description of the teachers' ability in implementing their task involving professional competence in teaching English. The researcher wants to view, analyze then describe the profile of English teachers' professional competence at SMA Negeri 1 Enrekang.

\section{Teachers' Competence}

The term teachers' competence has several meaning. Broke and Ston in Mulyasa (2009:25) stated that teachers' competence is the description of qualitative nature of the teachers' behavior appearing to be entirely meaningful. While Charles in Mulyasa (2009:25) defined competence or competency is a rational performance which satisfactorily meets the objectives for a desired condition. Whereas in $U U$ RI No. 14/2005, it explained that competency is a set of knowledge, skills, and attitude that teacher has to had, inspires, and masters in implementing their duty of professiolism. In Indonesia, the teacher who meet the standards of being professional teachers are they who have required qualifications and truly understand what to do, whether inside or outside the classroom.

From definitions above, it can be stated that competence refers to the ability to implement what the teacher has gained from education. The teachers' competence refers to the rational performance and action to complete certain things in implementing the educational duty. Competence is the ability to implement what they have achieved or gained from education and training. Competence is very contextual and non-universal for every kinds of profession. UU No. 14/2005 section 8 stated that a teacher is obliged to have academic qualification, competence, teacher's certificate, and the ability to realize the purpose of national education. Furthermore, section 10 subsection (1) states that teacher's competence as written in section 8 consists of pedagogical competence, personal competence, professional competence and social competence. In this research, the researcher focused on professional competence of English teacher, in this case identifying the profile of English teachers' professional competence.

\section{a. Professional Competence}

Professional competence can be defined as the teachers' capability to master their subjects in-depth and the way to appropriately deliver it to the students (Hung, et al in Syahruddin, 2013:144). Apart from teaching, teachers should possess the capability to diagnose students' initial behavior, develop lesson plans, administration, communicate, and develop themselves as well as the students' potential (Rusman in Syahruddin, 2013:144). In order to play those particular roles, teachers should trade on their educational background and experiences.

National Education Standards, phase 28, line 3, clause (c) states that professional competencies refer to the mastery of education in depth which enables teachers to guide students and manage teaching activities.

\section{b. The Sub-Competences of \\ Professional Competence}

Professional competencies include expertise in its field or mastery of the material that is to be taught along with the method, a sense of responsibility of his duty and sense of community with other teacher colleagues. Gumelar and Dahyat (2002:127) refers to the opinion of the Asian Institute for Teacher Education, said teachers' professional competence in the 
case include the ability to (1) understand and implement good educational foundation of philosophical, psychological, and so on, (2) understand and apply the learning theory according to the developmental level of the learner's behavior, (3) be able to handle or field of study subjects assigned to him, (4) understand and apply the appropriate teaching method, (5) able to use a variety of tools and media studies as well as other learning facilities, (6) is to able to organize and implement the programs, (7) is able to carry out the evaluation of learning and (8) is able to motivate learners.

Johnson in Anwar (2004:63) argues professional competencies include (1) mastery of the recent lessons that to be taught, and the basic concepts of materials that are going to be taught, (2) mastery and appreciation of the foundation and educational insights and teacher, (3) control of the processes of education, teacher training and student learning. Arikunto (1993:239) suggests professional competence requires teachers to have a broad knowledge of the subject matter and the subject matter (field of study) will be taught as well as mastery of the methodology is to master the theoretical concepts, as well as choosing the appropriate method and is able to use it in teaching and learning process.

Ministry of Education (2004:9) argues professional competence includes professional development, understanding insight, and mastery of academic study. Professional development includes (1) following the development of science and technology information that supports the profession through scholarly activities, (2) transfer the textbooks / scientific papers, (3) develop various models of learning, (4) write a paper, (5) write / compile textbook lesson, (6) writing textbooks, (7) writing module, (8) writing scientific papers, (9) conduct scientific research (action research), (10) finding the appropriate technology, making props / media, (12) create the artwork, (13) join accredited training, (14) joins the educational qualifications, and (15) joins the curriculum development activities..

Understanding insights include (1) understand the vision and mission, (2) understand the relation between education and teaching, (3) understand the concept of primary and secondary education, (4) understand the function of the school, (5) identify the common problems of education in terms of process and outcomes of learning, (6) establish a system that shows the linkage of education and academic study beyond the schools.

Mastery of academic study include (1) understanding the structure of knowledge, (2) master the material substance, (3) controlled substance authority in accordance with the type of services students needed.

According to description above, the professional competence of teachers is reflected in the indicator (1) the ability to master the subject matter, (2) the ability of research and preparation of scientific papers, (3) the ability of professional development, and (4) knowledge and understanding of the educational foundation.

In this research, researcher uses the sub-competences of professional competence according to Permendiknas No. 16/2007 section 1, subsection 1 that sub- competence of professional competence includes: 1) Mastering the material, structure, concept, and scientific thinking to support their teaching and learning process. 2) Developing their professional competence through reflective act.

According to National Education Standards, phase 28, line 3, clause c, professional competence refers to the 
mastery of education in depth which enables teachers to guide students and manage teaching activities. According to the definition, there some issue that teacher should pay attention (Mulyasa, 2011:138) as follows:

\section{The Types of Learning Materials}

According Hasan in Mulyasa (2011:139) there are some criteria that must be considered in selecting and determining the standard material that will be taught to students as follow:

\section{a) Validity}

Before providing teaching materials, the teacher must be sure that the material has been verified. This means that teachers should avoid giving the actual material that is questionable or debatable. This is to avoid misconceptions, misinterpretations or incorrect usage.

b) Significance

Material should be relevant to the circumstances and needs of the students, making it useful for their life. The materials should be applicable in the development of academic skills to the next level and its applicability as a preparation for students' life.

c) Relevance

The materials should be Relevance to the ability level of students, meaning not too hard, not too easy and adapted to the local environment and the needs of the variation in employment and society

\section{d) Interest}

The material should be able to motivate learners so that learners have an interest to identify and develop skills further and more in-depth than what is provided through learning process in the school.

e) Satisfaction

Satisfaction in this case is the result of lessons that the students gain that are really useful for their life, and learners can truly work with the use and practice of science.

\section{2) Arrange the Learning Materials}

According to Gagne in Mulyasa (2011:146), there are eight categories of learning as follows:

a) Signal Learning.

This is the simplest form of learning, and consists essentially of the classical conditioning first described by the behavioral psychologist Pavlov. In this, the subject is 'conditioned' to emit a desired response as a result of a stimulus that would not normally produce that response. This is done by first exposing the subject to the chosen stimulus (known as the conditioned stimulus) along with another stimulus (known as the unconditioned stimulus) which produces the desired response naturally; after a certain number of repetitions of the double stimulus, it is found that the subject emits the desired response when exposed to the conditioned stimulus on its own. The applications of classical conditioning in facilitating human learning are, however, very limited.

b) Stimulus-response learning.

This somewhat more sophisticated form of learning, which is also known as operant conditioning, was originally developed by Skinner. It involves developing desired stimulus-response bonds in the subject through a carefullyplanned reinforcement schedule based on the use of 'rewards' and 'punishments'. Operant conditioning differs from classical conditioning in that the reinforcing agent 
(the 'reward' or 'punishment') is presented after the response. It is this type of conditioning that forms the basis of programmed learning in all its various manifestations.

\section{c) Chaining.}

This is a more advanced form of learning in which the subject develops the ability to connect two or more previouslylearned stimulus- response bonds into a linked sequence. It is the process whereby most complex psychomotor skills (eg riding a bicycle or playing the piano) are learned.

d) Verbal association.

This is a form of chaining in which the links between the items being connected are verbal in nature.

Verbal association is one of the key processes in the development of language skills.

e) Discrimination learning.

This happens when learners can differentiate similar stimuli. For example, learners can differentiate when they use simple present tense and when they use simple past tense

f) Concept learning.

This happens when learners can classify the form of category of the lesson. For example they can categorize the characteristics of simple present tense and simple past tense.

\section{g) Rule learning.}

This is a very-high-level cognitive process that involves learning relationships among concepts and applying these relationships in different situations, including situations not previously encountered. It forms the basis of the learning of general rules, procedures, etc.

h) Problem solving.
This is the highest level of cognitive process according to Gagné. It involves developing the ability to invent a complex rule, algorithm or procedure for the purpose of solving one particular problem, and then using the method to solve other problems of a similar nature.

\section{3) Organizing Learning Materials}

In organizing learning materials, According to Mulyasa (2011:149) teacher can use Reigeluth's elaboration theory. Procedures of Elaboration Theory are:

a) The Presentation of epitome.

This step presents the structure of the learning material in the form of a general overview of the most basic, most important, and most easy to be understood

b) The first stage of elaboration.

It describes each step of each section that are presented in epitome, ranging from the most important part to the other parts in sequence, and ends with summary and synthesis.

c) The second stage of elaboration.

This step explains more detail for each sub-section on the first stage of the elaboration according to learning objectives.

d) Giving a summary and synthesis.

At the end of the first stage of elaboration, give the summary from all parts that have been elaborated. Synthesis shows the relationship between the parts that have been elaborated and inter-section with the epitome, which is presented at the end of the first stage of elaboration.

e) Summary and final synthesis.

This step is the final step of learning, with presenting the synthesis and summary that covers the entire learning material. 
According to Mulyasa (2011:155)

there are some considerations in organizing learning materials are as follows:

a) The subject matter should be tailored to the developmental level of the students, both the development of knowledge and ways of thinking as well as social and emotional development. Implementation of learning should be regulated in such a way so not boring and burdensome for learners.

b) Learning material should be arranged with the principle; proceed from the concrete to the abstract, developed from the known to the unknown, starting close to the distance, developed from long experience to new experiences, and start from simple to complicated.

c) Learning materials should be selected that are meaningful and useful for the learners in their daily lives, especially to develop themselves in society, either for living or as a basis for developing their career.

d) Learning materials should help the learners to be actively involved, either through their own thinking and by doing various activities.

e) Learning materials should be flexible, according to the needs and environment of the learners. Teachers should be able to develop a media and a variety of learning resources.

f) An instructional material in each subject group is intact, based on standards of competence and basic competences, gives meaning and beneficial for students.

g) Calculate the Allotment of time for each lesson.

\section{4) Utilize Learning Resources}

According to Mulyasa

(2011:157), learning resources can be grouped as people, material, setting, tools and equipment, and activities. In utilizing learning resources, teachers should pay attention on some steps as follows:

a) make a good preparation in selecting and using any source of learning in order to support the effectiveness of learning

b) choose learning resources that are appropriate with the standard material being studied and support the achievement of objectives, and the establishment of competence

c) Understand the strengths and weaknesses of the source that are going to be used, and analyze its contribution to the process and learning outcomes when using these learning resources.

d) Do not use a source of learning just for entertaining, but it should have a purpose that is integrated with the material being studied.

e) Learning resource should be suitable with available cost.

\section{5) Selecting and determining learning materials}

According to Mulyasa (2011; 165), there are some principles in selecting and determining learning materials as follows:

a) Orientation on goals and
competencies

Development of learning materials should be directed to achieve the goals and form competence of learners. The national education goals are described into the content standards, competency standards, and basic competence, which needs to be described back into the indicators of 
teacher competence. By the standards of competence and basic competences, teacher develops standards materials to establish the competence of learners.

b) Relevance

Learning materials must comfort with the requirements and conditions of the community, the level of development of learners, learners needs in their daily lives, as well as the development of science, technology, and art.

c) Efficient and effective

Learning materials should be prepared according to the principle of efficiency in utilizing the funds, time, personnel, and other sources available in the school in order to achieve optimal results, and also to increase the effectiveness or success of learners.

d) Fundamental

Learning materials should prioritize fundamental of learning materials , essential, or potential. It means the basic learning materials should form the competence of learners , so that other materials beyond that will be easily absorbed, because it is a foundation to mastery the standards of competence.

e) Flexibility

Learning materials should be is flexible so it is easily customized, modified, supplemented or reduced according to community.

f) Sustainable and balanced

Learning materials should be arranged continuously so that each aspect cannot be separated off, but have a functional and meaningful relationships.

g) Validity

Before providing teaching materials, a teacher must be sure that learning materials have been verified. This means that teachers should avoid giving the material in question or still debatable. This is for avoiding misconceptions, misinterpretations or incorrect usage.

h) Significance

Learning materials should be relevant to the circumstances and needs of the students so that the material is useful for learners.

i) Relevance

Learning material is not too hard, not too easy and adapted to environment and the needs of community for current and future.

j) Interest

interesting is not just attract the attention of students when learning but the material should be able to motivate learners so that learners have an interest to identify and develop further skills which is given by learning in schools .

k) Satisfaction

The results of learning that have been obtained by learners can really be beneficial to life, and learners can truly work with them.

\section{RESEARCH METHOD}

\section{A. Research Design}

This research employed descriptive evaluative method. Descriptive research aims to provide a clear, accurate description of individuals, events, or process (Gall, 2005:179). Furthermore, evaluative or evaluation research is the systematic process of collecting and analyzing data about the quality, effectiveness, merit, or value of programs, 
products, or practice (Gay, 2007:7). In this research, the researcher provided the description of profile of English teachers' professional competence at SMK Negeri 1 Makassar.

\section{Teachers' Professional Competence}

Professional competence can be defined as the teachers' capability to master their subjects in-depth and the way to appropriately deliver it to the students. In this research, the researcher focused on sub-competence that is stated in the Indonesia Standard National of Education that professional competence deals with sub-competences which are teachers' competence in mastering concept, structure, the learning materials, and scientific thinking to support teaching and learning process and developing professional competence through reflective act.

\section{Students' Achievement}

Students' achievement in this research refers to the students' ability in English that can be seen in their score from their book report. In this research, the researcher only took students' score in their final semester. The researcher would see the whether there was relationship between teachers' professional competence and students' achievement

\section{B. Population and Sample}

\section{Population}

The population of this research was all English teachers and students in SMK Negeri 1 Makassar. In this school, there are five English teachers and three departments namely accounting, administration office and marketing.

\section{Sample}

In selecting the sample, the researcher used purposive sampling technique. The researcher chose certified
English teacher of all English teachers at SMK Negeri 1 Makassar. There were five certified English teachers but researcher only chose three teachers representing: First was teacher who taught the third grade and second and third were teachers who taught the second grade. Whereas, sample of the students were who were taught by that teacher.

\section{Instruments of the Research}

\section{Classroom Observation Checklist}

Classroom observation checklist was used by the researcher to obtain the data by simply watching the participants when teaching and learning process taking place. Marshall in Sugiyono (2009:226) states that through observation, the researcher learned about behavior and the meaning attached to those behaviors. In this research, the researcher saw the activity in the classroom and records it. The researcher used observation matrix referring to professional competence. The observation matrix covers some criteria that are scored with final score 1 to 4. Each score can be categorized as: $4=$ high (very good), $3=$ medium (good), $2=$ low (poor) and $1=$ very low (very poor) (Mulyasa, 2009:214).

\section{Interview Guide}

Estenberg in Sugiyono (2009; 231) defines interview as a meeting of two persons to exchange information and idea through questions and response, resulting in communication and joint construction of meaning about a particular topic. In this research, interview was a purposeful interaction in which the researcher tries to obtain information from the teachers and the students to clarify and support the data from observation. The interview questions consists of some structured questions that asked the teachers about professional competence. The interview is semi- structured interview in 
which the researcher asks questions that previously structured and then it is continued by asking other questions related to the teachers' answer to get deep data about the variable (Arikunto. 2006:227), in this case the profile of English teachers' professional competence. The researcher used a recorder as the interview device.

\section{Procedure of Collecting Data}

The procedure of collecting data covers several steps. First, the researcher visited the school in where the teachers as the sample of this research. The second step, the researcher explained to schools officers about the purpose of the study and the procedures would be involved. The third step, the researcher met the English teachers to decide the time when the researcher observed the teaching and learning process and conduct the interview. The forth step, the researcher observed teaching and learning process in the classroom for four meeting for each teacher. The last step, the researcher interviewed the English teacher

\section{E. Technique of Data Analysis}

Descriptive analysis is used in analyzing the data, in which the researcher analyzed the data collected through the instruments previously mention. Firstly, the researcher collected the data that was gained by observing the teaching and learning activity in the classroom and next interviewing the English teachers and also the students. Secondly, the researcher analyzed the data through data reduction in which the researcher summarized, chose the main things, and focused on the important points. After reducing the data, the next step was data display, in which the researcher analyzed and described the data quantitatively. Miles and Huberman in Sugiyono (2009:249) states that looking at displays helps us to understand what is happening and to do something further analysis or caution on that understanding. The last step was conclusion (drawing/verifying) in which the researcher took the conclusion about the result of analyzing the data.

\section{FINDING AND DISCUSSION}

This part discusses the result of the research based on the research questions in the chapter 1 . It describes the profile of English teachers' professional competence and students' achievement at SMK Negeri 1 Makassar. There were three English teachers as the sample of this research. They all are certified English teachers. In order to get the data of this research, they were observed by the researcher in the classroom while teaching and learning process taking place. They were also interviewed by the researcher in order to get information and clarify some reasons for conducting the activities they did in the classroom during observation.

The teachers' professional competence itself, as what has been explained in the previous chapter, consists of two sub-competences. The following are the further descriptions of the research findings.

According to the data collected during observing the teaching and learning process in the classroom and interviewing the teachers, there were some important points that the researcher found related to the profile of the English teachers' professional competence of SMK Negeri 1 Makassar. The profile of English teachers' professional competence was identified based on the two sub- competences of professional competence. Each subcompetence covers some characteristics. 


\section{Teachers' competence in mastering the material, structure, concept, and scientific thinking to support their teaching and learning process}

The first sub-competence of professional competence is the teachers' ability in mastering the material, structure, concept, and scientific thinking to support their teaching and learning process. This sub-competence covers some points (see Appendix I). The teachers' competence in mastering the material, structure, concept, and scientific thinking to support their teaching and learning process is viewed in the following explanation.

\section{a. Teachers 1}

The first teacher was observed by the researcher for four times, on $5^{\text {th }}, 7^{\text {th }}$, $8^{\text {th }}$, and $9^{\text {th }}$ May, 2014 and interviewed in the school office on May $9^{\text {th }}, 2014$.

The profile of the first English teacher' professional competence in mastering the material, structure, concept, and scientific thinking to support their teaching and learning process is explained in the following paragraph.

In this case the teacher' ability to master the material, structure, concept, and scientific thinking to support her teaching and learning process, in which this sub-competence covers six important points (see Appendix I). Based on the observations conducted by the researcher toward the first teacher, the result shows that the first teacher's score is 4 (very good) that score was gained by the calculating all score of each point as written in the observation matrix (see Appendix IV). It indicates that the first teacher has very good competence in mastering

the material, structure, concept, and scientific thinking to support her teaching and learning process.

Starting from the first indicator of this sub-competence, the researcher found in the observation that the teacher mapped the standards and basic competencies for her subjects to identify learning materials that are considered as difficult, lesson plan and its implementation, and estimate the allocation time, it can be seen in her syllabus that she had used. The researcher found that standards, basic competencies and allocation time in teaching have been formulated by the government in terms of SMK's MGMP forum in Makassar area.

Based on the observation, the researcher found that the materials that she gave to the students still made students confused because but she did not make it in one module. The students had to bring two books in the class and the teacher would ask which book they were going to use today. She did not put it all materials in one package.

In organizing learning materials, the researcher found that the teacher started the materials from simple to complicate. She related the materials with students' life and tried to make students actively involved in teaching and learning process by giving group working or discussion. But she did not focus on the flexibility of the materials according to the needs and environment of the learners because the researcher found materials in Vocational schools were still in general English not focus on their department.

The data above can prove that the teacher could master the material, structure, concept, and scientific thinking to support her teaching and learning process. She not only took all materials from book that government have prepared, but also she arranged it based her students' and school/area conditions even she was not put it in one package/one module.

\section{b. Teacher III}

The third teacher was observed by the researcher for four times, on May $5^{\text {th }}$, $9^{\text {th }}, 10^{\text {th }}$ and $12^{\text {nd }}, 2014$ she was interviewed in the counseling office on 
May $12^{\text {th }}$, 2014. The following explanation presents the profile of the second English teacher's professional competence in terms of the first subcompetence.

Based on the observation conducted by the researcher toward the second teacher, the result shows that the second teacher's score is 2 (low) (see Appendix IX). It indicates that the second teacher is not as good as the first and second teacher. Nevertheless, it is not only one way to see the competence of the third teacher in terms of the first sub-competence.

The teacher could map the standards and basic competencies for her subjects and estimate the allocation time, it can be seen in her syllabus that she had used. The researcher found that standards, basic competencies and allocation time in teaching have been formulated by the government. The teacher only used the syllabus that are made by all SMK English teachers in Makassar in MGMP forum as agreement but still related to the curriculum from the government (see Appendix V).

In relation to the difficult materials, the supporting data gained from interview indicated that for difficult materials the teacher used an approach method to the students who didn't understand it.

\section{DISCUSSION}

\section{Teacher competence in mastering the learning materials, structure, concept, and scientific thinking to support their teaching and learning process}

Based on the data gained from observing the teaching and learning process and interviewing the English teachers, the English teachers' competence in mastering the learning materials, structure, concept, and scientific thinking to support the teaching and learning process showed the score of each teacher; teacher $\mathrm{I}=4$ (very good), teacher II $=($ good $)$, and teacher III $=2$ (poor). Mulyasa (2011;

138) stated that three are at least four things should be understood by the teachers related to this subcompetence; understanding the types of learning materials, arranging the learning materials, utilizing learning resources and selecting and determining learning materials.

First point in mastering the learning materials, structure, concept, and scientific thinking to support the teaching and learning process as stated by Mulyasa is about the ability of the teacher to spell out learning material according to the curriculum.

According the gained data from interview, all teachers could map the standard, basic competence and allocation time in teaching English because it had been formulated in MGMP forum. The jobs for the teachers were selecting and determining their material based on their students' condition because every school has different condition.

The teachers have to have ability in decide the learning material that relevance with the students need and students' ability. According to Hasan in Mulyasa $(2011 ; 139)$, there are five points in selecting and determining learning materials that the teachers have to pay attention; they are validity, significance, relevance, interest, and satisfaction of the materials.

Based on the findings, there are two teacher (teacher I and teacher II) could understand the types of learning materials. They select and determine the learning materials based on the students condition. They select which materials that suitable for their students' condition. They took materials from many recourses. If the material that they have found is not suitable for their students' condition even 
the materials are based on the syllabus, they still would arrange it relating to the students; condition. For teacher III, she selected and determined the material but she didn't arrange it if the material is not suitable for students' conditions, she only focused on the materials that are based on the syllabus.

Nevertheless, the learning materials in the school are still in general. Some of the materials are not focus on students department. Mulyasa (2011:139) stated that the learning material should give students knowledge that they can use or apply it in their future job/field of study. According from observation data, it indicates that all materials for each department (accounting, office administration, and marketing) in the school are the same.

In relation to the difficult materials, based on the gained data, all teachers have different method to solve this problem. But the main point in solving the problem is the teachers use different method based on the students' ability in particular class.

In relation to the organizing learning materials, based on the findings, all teachers started the learning material from simple to complex. Besides, they always pay attention the class ability in particular class. Possibly, there were some students getting slow in thinking to understand the given materials and there also who get fast in thinking to understand the material. Whatever the student's cognitive ability is, the teacher should understand it and responsible to help the student. The teachers should pay attention to the different characteristics or ability of the students in organizing learning material.

\section{Teachers' competence in developing their professional competence through reflective act}

Based on the findings, the score of the teachers in developing their professional competence through reflective act are: teacher $\mathrm{I}=2$ (low), teacher $\mathrm{II}=1$ (very low), and teacher III $=1$ (very low). From the data, it indicates that all teachers are low in this sub-competence.

The first important point in this sub- competence is the teachers do selfevaluation and assessment in their teaching. All teachers actually did selfevaluation and assessment. According the data from findings, Teacher I, teacher II and teacher II did self-evaluation by changing their method if they felt the particular method in the particular class is less successful. They realized that every student had different cognitive ability and individual differences. According to Bean in Engaging Ideas (1996: 39-40), the students' personalities are various, that is why the teachers need to know it. Nevertheless, based on the observation and interviewing, all teachers did not make a written report about their self-evaluation and assessment. So it is difficult to know their progress in teaching.

In relation to the doing classroom action research and joining professional development program, the finding shows that all teachers did not do it. But some of them (teacher I and teacher II) are still in progress their classroom action research. According to the observation, all teachers never join professional development program but they only followed the seminar.

Based on the findings, all teachers are actively involved in many seminars that related to the education to develop their ability.

The last indicator in this subcompetence is using ICT to support teaching and learning process. Based on 
the finding, only Teacher I used ICT in the teaching and learning process. Teacher II and teacher II had reason why they didn't use ICT. Teacher II had eye problem and teacher III could not operate computer. But they use other media in teaching. According to the findings, teacher II usually used tape recorder and colorful card. Teacher III admitted that she used media, based on the observation for several meetings, but the researcher did not see any evidence that she used media in teaching and learning process.

All teachers realized that using ICT or media in teaching and learning process could develop their students' motivation in learning process. Based on the findings teacher I said that Using ICT could make students more interested in learning and she emphasized that it is not only helpful for students but also for teachers. Moreover, teacher II used media in teaching and learning process because it made students easy to involve in teaching and learning process actively. Besides for teacher III, she stated that using media could make students more interested in teaching and learning process.

Using ICT in teaching and learning process could develop students' motivation in teaching and learning process. Furthermore, Elmaifi (2014) stated that it has been proved that using ICT has lots of benefits on the students such as ICT allow for a higher quality lessons through collaboration with teachers in planning and preparing resources (Ofsted, 2002); Students learn new skills: analytical, including improvements in reading comprehension (Lewin et al, 2000); ICT also develop some writing skills: spelling, grammar, punctuation, editing and re-drafting (Lewin et al, 2000). Still new technologies encourage independent and active learning, and students' responsibility for their own learning
(Passey, 1999) ICT proves that students who used educational technology felt more successful in school they are more motivated to learn more and have increased self- confidence and selfesteem. It is also confirmed that many students found learning in a technology-enhanced setting more stimulating and much better than in a traditional classroom environment (Pedretti and Mayer-Smith 1998).

English today must include knowing how to read, write and communicate in electronic environments. For most teachers and professionals, learning how to compose electronic mail or make effective use of the World Wide Web involves English language skills that should be considered as essential part in teaching English. According to the school condition where three departments in the school are really need know about ICT in relation to English as the knowledge to their future job.

\section{CONCLUSION}

There are some conclusions related to the findings and discussion in the previous chapter.

1. Based on the findings and discussion, it can be concluded that the three teachers have different quality in terms of professional competence. For the first subcompetence, mastering concept, structure, learning materials, and scientific thinking to support their teaching and learning process, two (teacher I and teacher II) are categorized as good enough, especially teacher I. They pay attention to the material that will be given to the students. Organizing the materials by making their own module.

2. In terms of the second subcompetence, developing professional competence through reflective act, all 
of the teachers have less effort in developing their professional competence. All of them don't make report of self- evaluation and assessment. Moreover, they don't make any classroom action research and join professional development program but they are actively involved in many seminars. For using ICT in teaching and learning process, only teacher I that used it. Teacher II and teacher III didn't use ICT only use other media such as card.

3. Since the teachers' quality is the most important point in developing the students' learning proficiency, the three English teachers could not be categorized as the qualified teachers. They have not been professional teachers yet, because in Indonesia, the teachers

who meet the standard of being professional teachers are the ones who have required all the qualifications of teachers' competence. Finally, it can be concluded that the three English teachers still need more improvement. However, comparing with other two teachers, the researcher concludes that teacher I is the best one.

4. The data from findings indicates that the highest students' score is from teacher III. Meanwhile, the highest score of teacher professional competence among those teachers is teacher I. It indicates that many factors that competence. So we could not say that only professional competence influence students' achievement in learning English.

\section{BIBLIOGRAPHY}

[1] Allman Barbara, Freeman Sara, Owen Jeffrey, Palow Sally, and ShiotsuVicky. 2000. Skills for Successful Teachingi. McGraw-Hill Children's Publishing.

[2] Anwar, Moch. Idochi. 2004. Administrasi Pendidikan dan Manajemen Biaya Pendidikan. Bandung: Alfabeta.

[3] Arikunto, Suharsimi 1993. Manajemen Pengajaran Secara Manusia. Jakarta: Rineka Cipta

[4] Bean, J. C. 1996. Engaging Ideas: The Professor's Guide to Integrating writing, Critical Thinking, and Active Learning in the Classroom. Retrieved on April 21 ${ }^{\text {st }}, 2014$ from http:/web.Presby.edu/writingcenter/ newsletter/ studentpref. Html

[5] Dictionary Reference. 2014. Definition of Profile. Retrieved on January $\quad 8, \quad 2014$ from dictionary. reference. com/browse/profile

[6] Definition. 2014. Definition of Profile from Webster's New World College Dictionary Retrieved on January8, 2014 from www. definitions. net/ definition/ Profile

[7] Definition. 2014. Definition of Profile from Cambridge

Advanced Dictionary. Retrieved on January 8, 2014 from www.definitions.net/definitio n/Profile

[8] Elmaifi. 2014. Advantages of Using ICT in Laearning-Teaching Process. Retried on May $19^{\text {th }}$,

[9] 2014 from http://edtechreview.in/trendsinsights/insights/959- advantagesof-using-ict-in- learning-teachingprocesses

[10] Gall, M.D, Gall, Joyce.P, and Brog, Walter R. 2005. Applying Educational Research: A Practical 
Guide. United Stated: Pearson Education

[11] Gay, L.R, Millis, Geoffrey E, and Airasian, Peter. 2006. Educational Research, A Practical Guide. New Jersey: Pearson Prentice Hall.

[12] Gumelar dan Dahyat. 2002. Administrasi Pendidikan Dasar Teoritis dan Praktis Profesional. Bandung: Angkasa

[13] Hanafiyeh, Masoomeh. 2013. The Relationship Between Iranian Efl Learners' Multiple Intelligence And Success In Foreign Language Learning. Asian Journal Of Management Sciences And Education. Vol. 2. No. 1. January 2013

[14] Harmer Jeremy. 1991. The Practice of English Language Teaching; New Edition. New York: Longman Publishing.

[15] Jalal, F., Samani, M., Mae, C. C., Steverson, R., Ragate, B. A., \& Negara, D. S. 2009. Teacher certification in Indonesia: A strategy for teacher quality improvement. Jakarta: Departemen Pendidikan Nasional.

[16] Kulshrestha, A.K. \& Pandey, Kshama. 2013. Teachers Training And Professional Competencies. Voice of Research Vol. 1 Issue 4. Pp : 29-33.

[17] Mulyasa, E. 2009. Standar Kopetensi dan Sertifikasi Guru. Bandung: PY Remaja Rosdakarya.

[18] Mulyasa, E. 2009. Uji Kompetensu dan Penelitian Kinerja Guru. Bandung: PY Remaja Rosdakarya.

[19] Mustafa, M. Nur. 2013. Professional Competency Differences among High School Teachers in Indonesia. International Education Studies. Vol. 6, No. 9. Pp: 83-92.
[20] Richards, J. C., \& Schmidt, R. 2002. Dictionary of Language Teaching And Applied Linguistics (3rd ed.). London: Longman.

[21] Sikki, Endang Asriyanti Amin., Rahman, Asfah., Hamra, Arifuddin., and Noni Nurdin. 2013. The Competence of Primary School English Teachers in Indonesia. Journal of Education and Practice Vol.4, No.11, 2013

[22] Surya, Muhammad. 2003. Psikologi Pembelajaran dan Pengajaran. Bandung: Yayasan Bhakti Winaya

[23] Sugiyono. 2009. Metode Penelitian dan Kualitatif dan $R$ \& $D$. Bandung:Alfabeta

[24] Syahruddin., Ernawati, Andi., Mohd. Anuar B. Abdul Rahman., Ahmad Johari B. Sihes. 2013. The Role of Teachers' Professional Competence in Implementing School Based Management: Study Analisys at Secondary School in Pare- Pare City of South Sulawesi Province-Indonesia. International Journal of Evaluation and Research in Education (IJERE) Vol. 2 NO. 3. Pp: 143 148

[25] Undang-Undang Republik Indonesia. 2007. Peraturan Menteri Pendidikan Nasional Republik Indonesia Nomor 16 Tahun 2007 Tentang Standar Kualifikasi Akademik Dan Kompetensi Guru. Jakarta: Depdiknas

[26] Zulfikar, Teuku. 2009. The Making of Indonesian Education: An Overview on Empowering Indonesian Teachers. Journal of Indonesian Social Sciences and Humanities. Vol. 2. Pp.13-39 